\title{
Kiszombor történeti demográfiája (1830-1839) az anyakönyvi vizsgálatok alapján
}

\author{
CAS \\ - Historical Demography of Kiszombor Based on the Examination \\ of Registers from 1830-1839 -
}

\begin{abstract}
My study is based on an empirical historical demographic analysis. I tried to present Kiszombor's society between 1830 and1839. The main sources of my research were the registers of the local Roman Catholic parish. I was able to track the local community's demographic changes and the contemporaries' careers as well by processing the ecclesiastical records of baptisms, marriages, and burials. The number of birth varies in the studied decade, but overall, it increased. The male-female ratio was around $50 \%$, there were bigger differences, but only by $5 \%$. The catholic priests baptized 155 children annually on average. From the ten most fashionable first names six was male, so I concluded the naming practice was more conservative for boys (just now). $13 \%$ of the baptized children got one of the parent's names, what is surprising.

The annual distribution of marriage shows growing tendency too. $58 \%$ of the marriages took place in the fall season, and $29 \%$ in winter. The average age of marriage was 28.5 years. The average age difference $88 \%$ of the cases in favour of men - was 6 years. Women were older in $5 \%$ of the relationships. The number of funerals was the greatest in 1831, because of the cholera epidemic. One third of burials took place in summer. Life expectancy at birth was 18.81 years, and $57 \%$ of children died before their $14^{\text {th }}$ birthday. In 1831 the cholera endangered mainly the children and people older than forty years. My historical demographic research of Kiszombor's population will be continued from decade to decade.

Keywords historical demography, church registers, number of birth, marriage, average marriage age, life expectancy, cholera, local history, social history, Kiszombor, $19^{\text {th }}$ century
\end{abstract}

DOI 10.14232/belv.2015.4.5

http://dx.doi.org/10.14232/belv.2015.4.5

Cikkre való hivatkozás / How to cite this article:

Körös Ákos (2015): Kiszombor történeti demográfiája 1830-1839 az anyakönyvi vizsgálatok alapján. Belvedere Meridionale 27. évf. 4. sz. 69-88. pp

ISSN 1419-0222 (print) ISSN 2064-5929 (online, pdf)

(Creative Commons) Nevezd meg! - Így add tovább! 4.0 (CC BY-SA 4.0)

(Creative Commons) Attribution-ShareAlike 4.0 International (CC BY-SA 4.0) 


\section{Tudománytörténeti előzmények: a történeti demográfia kialakulása}

A demográfia Hauser és Duncan szerint a múlt, a jelen és a jövő népességének az összetételével, állapotával, változásaival és ezek tényezőivel, továbbá a népesség és a társadalmi-gazdasági jelenségek kölcsönhatásával foglalkozó tudományág. Dudley Kirk szerint pedig a demográfia csupán a kvantitatív tanulmányozása az emberi népességnek. ${ }^{1}$

A történeti demográfia átalakulása a 20. század közepén kezdődött. Az első lépést 1955-ben Karl Helleiner Cambridge Economic History of Europe címü összefoglaló monográfiája jelentette, a másodikat pedig 1956-ban Michel Fleury és Louis Henry kötete, ami a Manuel de dépouillement et d'exploitation de l'état civil ancien (Régi anyakönyvek feldolgozásának kézikönyve) címet viseli. ${ }^{2}$ Ez utóbbi egy egészen új módszertant vezetett be a történeti kutatásban, amely forradalmasította a tudományterületet. A történeti demográfiának szüksége volt egy olyan forrástípusra, amelynek felhasználásával lehetséges átfogó képet adni az egykorvolt társadalmak szerkezetéről és demográfiai folyamatairól, az egyházi anyakönyvek pedig kiválóan alkalmasak erre. Minden fenntartás nélkül állíthatjuk, hogy „enélkül a statisztikai adatbázis nélkül nem létezhet történeti demográfia” ${ }^{3}$ Louis Henry (1911-1991) az egyházi születési, házassági és halálozási anyakönyvekre alapozta a történeti társadalmak demográfiai rekonstrukcióját. Ez az új módszer a családrekonstrukció (family reconstitution) néven vált ismerté. Az új módszer átalakította a történeti demográfia egész szemléletét, hiszen a gazdasági összeírások természetétől eltérően nem csak demográfiai metszeteket lehetett készíteni a társadalmakról, hanem úgynevezett longitudinális folyamatelemzéseket is. A születési, az esketési és a halálozási anyakönyvek az emberi élet három legfontosabb állomásáról adnak képet, s megfelelő forrásadottságok esetén az egész helyi társadalom demográfiai szerkezete a modern kor normái szerint is rekonstruálhatóvá vált.

Általános elfogadott tézis, hogy „nem érdemes falat húzni a történeti és a jelennel foglalkozó demográfia közé. Mindkettő hosszú távú, egymáshoz kapcsolódó folyamatokat vizsgál, bár a látószöge nem teljesen azonos." 4 A történeti demográfia a történettudomány része, de ugyanakkor köthető a biológiához (fizikai antropológia), az orvostudományhoz (közegészségügy), a filozófiához (népességelméletek) is. Ilyen módon a történeti demográfia a társadalom- és a természettudományok között elhelyezkedő interdiszciplináris tudomány. „Forrásai történetiek, elméletei a társadalomtudományokhoz kötik, módszere, szemlélete azonban a recens demográfiához, statisztikához és a természettudományokhoz kapcsolják."5

\section{A történeti demográfiai forrásai: az egyházi anyakönyvek}

Történeti koronként változik a történettudomány forrásainak köre, s ebből következően az alkalmazott kutatási módszerek eredményessége is. A történeti demográfia szempontjából Magyarországon az 1869-es esztendő jelenti a legfontosabb választóvonalat. Ezt megelőzően elsősorban adóösszeírásokra, egyházi anyakönyvekre és népszámlálásokra támaszkodhatunk. Ezek a források nem a népesedési folyamatok nyomon követésének szándékával készültek, hanem leginkább valamilyen államigazgatási célból, leggyakrabban adóalap felmérésének érdekében.

\footnotetext{
1 FARAgó 2006. 304.

2 Fleury - Henry 1956

3 FLINN 1981. 1.

${ }^{4}$ FARAgó 2006. 305-306.

5 FARAgó 2006. 304.
} 
Ráadásul ezek az összeírások, a II. József-féle népszámlálás kivételével nem vonatkozott az ország teljes népességre. Másik általános hiányosságuk, hogy a datálások gyakran problematikus. A statisztikai eszközök nem minden évszázadban alkalmazhatóak hatékonyan, ezért az adólajstromokra alapozott statisztikai idősorok gyakran megbízhatatlanok. Az adóösszeírások alapvetően a jobbágyság gazdasági helyzetére vonatkozó adatokat gyűjtenek össze, azonban az adóalapot koronként eltérően határozták meg. ${ }^{6}$

A történeti demográfiai kutatásokat hosszú időn keresztül az országos és megyei összeírások, adójegyzékek, dézsmajegyzékek és egyéb lajstromok számadataira építették. Az egyházi anyakönyvi kivonatok alkalmazása ezeket a kutatási eredményeket egészíti ki. Az anyakönyvek segítségével a társadalmat nem gazdasági, sokkal inkább szociális oldaláról tudjuk megvizsgálni. A személyes életpályák, illetve a családok müködésének perspektívájából szemlélhetjük az egykorvolt társadalmakat. A háromféle anyakönyv - keresztelési, házassági és temetési alkalmazásával nem kapunk választ minden történeti demográfiai kérdésünkre, de megfelelő forráskritikával, és különféle forrástípusok együttes felhasználásával árnyalt képet nyerhetünk a történeti társadalmak működési folyamatairól. ${ }^{7}$

Az első római katolikus anyakönyvet a 14. században kezdték vezetni Itáliában és Burgundiában, majd innen terjedt el a század végére szinte az egész kontinensen. A 16. században válik általánosan kötelezővé minden egyház számára az anyakönyvvezetés: 1538-ban Franciaországban, 1539-ben Angliában, majd a tridenti zsinatot követően (1563) minden római katolikus plébánián. A Köztes-Európa területén, illetve a keleti rítusú kereszténység országaiban azonban csak a 18. században honosodott meg az anyakönyvek vezetésének gyakorlata. A 19. században kezdődő szekularizáció következtében az anyakönyvezés elszakad az egyháztól és állami intézmények veszik át, de ez a folyamat Európában csak a 20. század közepére fejeződik be. ${ }^{8} \mathrm{Az}$ anyakönyvekre alapozott demográfiai rekonstrukció fontos gyengesége, hogy ezen az úton nem nyerhető információ a vándorlási egyenlegről.

Az anyakönyvek feldolgozása rendkívül aprólékos munkát igényel, amely (magyarországi) elterjedésének az egyik fő akadálya. A keresztelési anyakönyvek fontos hibaforrása, hogy a szülés közben elhalálozott csecsemöket nem minden esetben keresztelték meg, így a teljes termékenység egy összetevőjéről nincs semmilyen információnk. A megkereszteltek száma így nem minden esetben egyenlő a születettek számával. A születések nemek szerinti és időbeni eloszlása azonban jól rekonstruálható ilyen módon. ${ }^{9}$ A házassági anyakönyvekből kimutatható az egybekelések éven beüli eloszlása, valamint az, hogy milyen életkorban köttetnek a házasságok, s miként alakul a tradicionális társadalmakra oly jellemző újraházasodások rendje. A halotti anyakönyvek adatai alapján kiszámolható várható élettartamon túl következtethetünk a járványok hatásaira, $s$ általában véve az egészségügyi rendszer müködésének hatékonyságára, valamint a vizsgált korban általános halálozási okokra. „Az anyakönyvi adatok felhasználásával, a forráskritikai eredmények figyelembevételével megtett kiegészítések után a népességfejlődés folyamatáról kialakult egy kép, amelyből kitűnik a nagy járványok hatása, valamint az, hogy mikor, milyen mértékben vonzza a népességet a város, mikor és milyen mértékben történik a népesség kirajzása. Az anyakönyvi adatok alapján viszonylag egzaktan, bizonyos határértékek között lehetett a népességi folyamatot jellemezni."10

\footnotetext{
${ }^{6}$ Kovacsics 1963. 4-6.

7 Kováts 1983. 25-29.

${ }^{8}$ FARAGó 2006. 307.

9 KovÁts 1983. 29-31.

${ }^{10}$ Kováts 1983. 31.
} 
Az anyakönyvekre alapozott történeti demográfiai rekonstrukció legmagasabb szintje a családrekonstrukció, amelynek révén az emberi életpályák és a családok működése folyamatában szemlélhető. ${ }^{11}$ Etekintetben az első lépéseket Németországban tették meg, még az 1930-as években, amikor a falugenealógiai kutatásokat jelentős összegekkel támogatta a náci kormányzat. A történeti demográfiai szempontból jól felépített kutatómunka során hatalmas adatbázist hoztak létre, a további vizsgálatokat azonban a náci rendszer diszkreditálódása lehetetlenné tette. A francia Annales iskola 1950-es években, a német próbálkozástól teljesen függetlenül dolgozta ki a saját történeti demográfiai családrekonstrukciós módszerét. A nominális adatokon alapuló kutatásmódszertant innen vették át az angolszász kutatók, de a nem nominális, azaz adatok táblázatba rendezésén és ezek elemzésén alapuló módszertant már az angolok dolgozták ki. A történeti demográfia az 1970-80-as évekig több módszert is kifejlesztett, amelyek mindegyike anyakönyvek feldolgozását célozta. A nominális, azaz név szerinti elemzés további csoportokra osztható, ilyen például az aggregatív vizsgálat, amely az anyakönyvek adatait táblázatokba rendezi, és így elemzi; vagy a népszámlálásokra alapuló elemzések, mely utóbbi főként ÉszakAmerikában terjedt el. A családrekonstrukció alapja a genealógia családfa-összeállítása, de két fontos ponton el is tér attól. Egyrészt egy település összlakosságának életrajz-kialakítására törekszik, illetve az adatok csoportosításával olyan mutatókat lehet kiszámolni, amelyeket az egykori leírások alapján nem lehetne. ${ }^{12}$ „Nem hiába nevezték (...) a családrekonstituciót a történeti demográfia királyi útjának." ${ }^{13}$ Az Henry-féle családrekonstrukcióról szóló első kézikönyv 1956-ban jelent meg, az első magyar interpretáció ${ }^{14}$ pedig 1962-re készült el. A módszer lényege, hogy a kivonatolt keresztelési, esketési és temetési adatok alapján egy-egy család demográfiai viszonyait egy adatlapon egyesítették, és erre alapozva rekonstruálták a település népesedéstörténeti és társadalmi viszonyait. A módszert csak kis települések esetében bizonyult sikeresnek, nagyobb városok történeti demográfiai vizsgálatában már csak szúrópróba szerúen lehetett feldolgozni néhány rokonsági szálat. ${ }^{15}$

\section{Kiszombor földrajzi elhelyezkedése}

Kiszombor nagyközség ma az északi szélesség 46,183 fokán, illetve a keleti hosszúság 20,433 fokán található. A falu nevének eredete a középkorra nyúlik vissza, amikor is a Csanád nemzetség ősi birtokaként tartották számon Zumbur, Sombur, Zombár néven. Az oklevelek Sombornak, Szombornak és Zambornak is említik. Az 1800-as évek kezdetén kezdik el Kis-Zombornak nevezni, azonban ez az általam vizsgált korszakban az anyakönyvi kivonatokban nem tükröződik. 1890-es években a bácsmegyei Zombor miatt meg akarták változtatni a falu nevét, de a lakosok ragaszkodtak a hagyományos névhez ezért megmaradt a Kiszombor elnevezés. ${ }^{16}$ Mivel az általam vizsgált korszakban az adatokban a települést Zombor néven említik, a cikkemben is ezt az elnevezést használom a továbbiakban.

11 FLINN 1981. 1-2.

12 Faragó 2006. 315-316.

13 Öri 1998. 14.

14 Kováts-Tóth 1962.

15 KovÁts 1983. 32.

16 Kiss 1997. 5-6. 


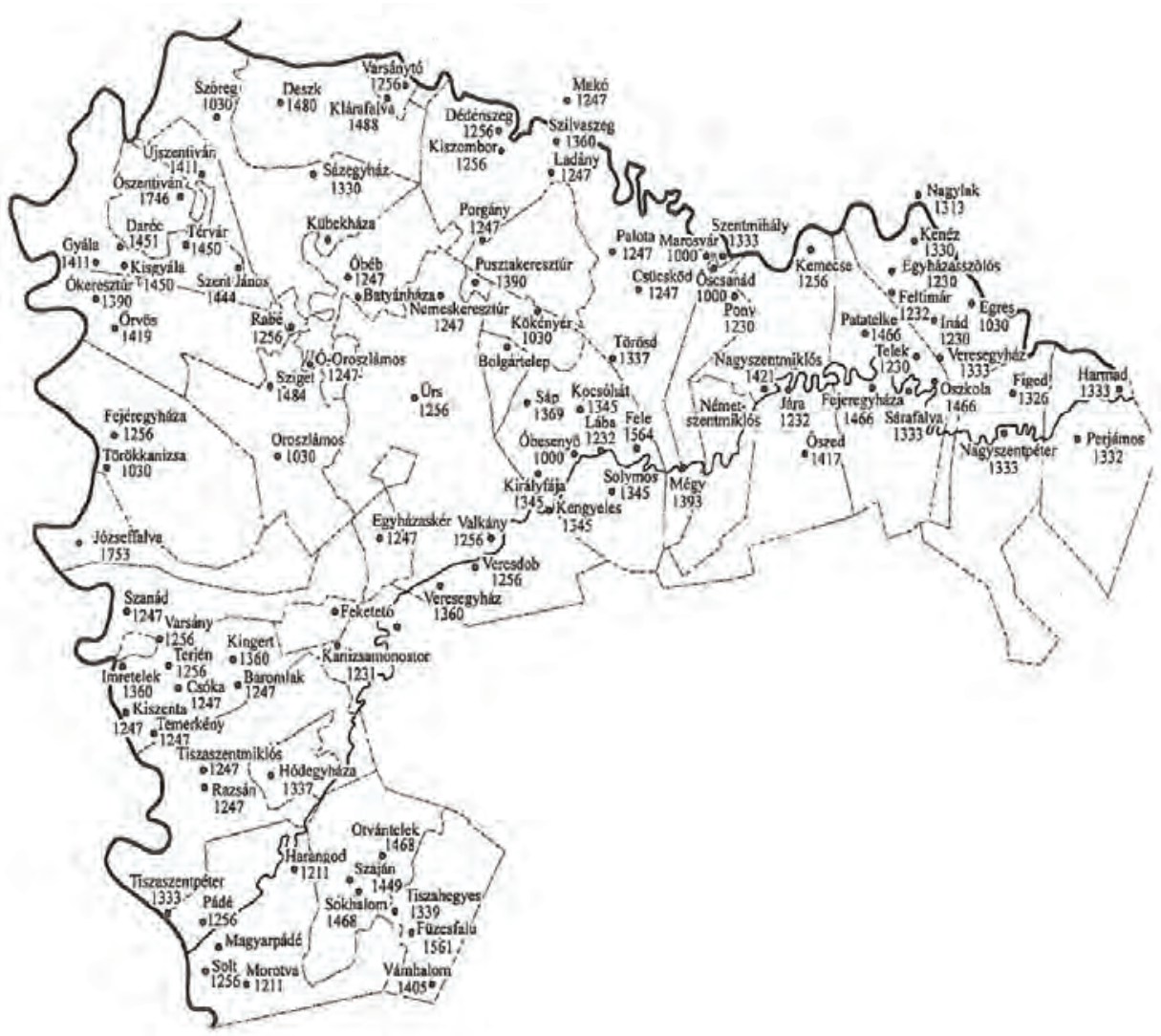

1. ÁBRA *A Marosszög településeinek első okleveles emlitése ${ }^{l /}$

A falu közigazgatása Alsó-Tiszavidékhez és azon belül is a Marosszöghöz tartozott. Az alföldi tájakat és a löszhátakat a Tisza és a Maros együttes munkája alakította. Zombor mellett a Maros meanderező ága folyamatosan formálta a tájat, aminek a következményei a mai napig megmaradtak. Bár a folyószabályozás során gátak közé szorították a folyót, az Ös-Maros medrei ott húzódnak a mai felszín alatt. Kiszombor területe nagyrészt ártéri síkság, lerakódott infúziós lösz, agyag, és homok a jellemző talajtípus. A relatív relief ${ }^{18} 1-2 \mathrm{~m} / \mathrm{km}^{2}{ }^{19}$ Péczely György alapján ${ }^{20}$ a vidéket a meleg-száraz éghajlati csoportba osztjuk. A globális napsugárzás, azaz a napsugárzás évi összege $4600 \mathrm{MJ} / \mathrm{m}^{2}$, ami az egyik legnagyobb érték a mai országhatárok között. A napfénytartam évi összege 2100-2150 óra között van. A napfénytartamot befolyásolja a felhőzet mennyisége: a Marosszögben a derült napok ${ }^{21}$ száma hatvan, míg a borult napok ${ }^{22}$ száma száz. Utóbbi viszonylag alacsony érték. A térség évi középhőmérséklete $11^{\circ} \mathrm{C}$ felett van. A korai kita-

\footnotetext{
17 KóKai 2008. 31.

18 Az egy négyzetkilométeren belüli legmagasabb és legalacsonyabb pontok viszonylagos különbsége.

19 KóKai 2008. 17-20.

20 PÉCzely 1998. 282-284.

21 A felhőzet mennyisége nem haladja meg a 20\%-ot.

22 A felhőzet mennyisége meghaladja a $80 \%$-ot.
} 
vaszodás (március hónap középhőmérséklete $6,3^{\circ} \mathrm{C}$ ), a júliusi $22,4^{\circ} \mathrm{C}$-os középhőmérséklet és a magas őszi értékek (október hónap 11,9-12 ${ }^{\circ} \mathrm{C}$-os középhőmérséklete) arra engednek következtetni, hogy a tenyészidőszak hosszabbra nyúlik, mint az ország más területein, így a melegigényes növényi kultúrák honosodtak meg a területen. A térségben 20-25 olyan nap van évente, amikor a napi maximumhőmérséklet nem haladja meg a $0^{\circ} \mathrm{C}$-ot. Ha a maximum hőmérséklet legalább $30^{\circ} \mathrm{C}$, akkor hőségnapról beszélhetünk. Kiszombor területén harmincnál több hőségnapról beszélhetünk, a hőmérséklet abszolút ingása pedig $70^{\circ} \mathrm{C}$-ot tesz ki. A csapadék átlagosan $600 \mathrm{~mm}$ évente, azonban ennek megoszlása nagyon változó. A csapadékos napok száma, azaz amikor legalább 1 mm csapadék hullik, évente 85-90 nap. Ebből 30-35 zivataros nap, amely elég magas szám, továbbá átlagosan 20 napon esik hó, ami legfeljebb 30-35 napig maradt meg. A csapadék egy része lefolyásra kerül, egy része pedig beszivárog a talajba, ugyanakkor a legnagyobb rész elpárolog, amely a növénytermesztés szempontjából nem hasznos. ${ }^{23}$

\section{Kiszombor társadalomtörténete}

A középkorban a terület a Csanád nemzetség tulajdonában volt, ugyanakkor egy-két okleveles említésen kívül nincs hírünk a faluról. 1256-ban felosztották a birtokokat a nemzetség fiai között, majd 1360-ban a nemzetség Telegdy ágának egyik ága, Kelemen utódai Zomborra költöztek, és itt építették fel kúriájukat, így kiemelték a többi jobbágyfalu sorából Zombort. ${ }^{24}$ 1514-ben a térségben robbant ki a parasztfelkelés, amely hatalmas pusztítással járt, majd a hanyatlást a török hódítás tetőzte be. Az 1560-1561-es török adóösszeírás már senkit nem talált a faluban. 1647 tavaszán katolikus családok betelepülése kezdődött meg, valószínűleg Erdély felől, és az, hogy pont ezt a területet választották, minden bizonnyal két okra vezethető vissza. Egyrészt a Maros kapcsolatot és megélhetést, a folyó mocsarai pedig védelmet jelentettek a letelepülők számára, másrészt pedig az elhagyatott pusztaságban találtak egy körtemplomot, amelyet a törökök is tiszteletben tartottak. ${ }^{25} \mathrm{~A}$ terület a török kiűzése után előbb vélhetően Rákóczi birtok volt, ${ }^{26}$ majd a Temesvári Bánsághoz tartozott. A kormányzat igyekezett kisajtolni a lehető legtöbb hasznot a területből, így Zomborból is. Gyakoriak voltak az adóterhek alóli szökések, de a hatóságok rendre visszahozták az elfutottakat. Nemegyszer megtörtént, hogy a jobbágyok nem csak elmenekültek, hanem még a házaikat is felégették. Ennek az lett a következménye, hogy a területi kormányzat 1725-ben áthelyeztette a határőrséget Zomborra. 1733-ban éhínség, 1737-1738-ban pedig pestis pusztított. A falu 300 lelket számláló lakossága 1742-ben megpróbált törvényes úton Bébre költözni, de ez az erőfeszítés is eredménytelen volt. Az adóterhek és a gyenge közbiztonság ellenére 1784-1831 között a falu lakossága megháromszorozódott. 1780-ban a település 149 családja összesen 894 lelket számlált. 1831-es adatok alapján pedig már 2888-an laktak Zomboron. ${ }^{27}$ 1781-ben Oexel Mátyás József, nagyszentmiklósi sörgyáros megvásárolta Zombort a kincstártól. ${ }^{28}$ „Magától értetődik, hogy az így eladott uradalmakkal a hozzájuk tartozó úrbéres községek is velejártak, melyek csak az 1848-as birtokmegváltással szakadtak el az uradalomtól." 29

\footnotetext{
23 Kókai, 2008. 20-23.

24 Kiss, 1997. 109.

25 KISs 1997. 59-70.

26 MarJanucz 2008. 210.

27 Kiss 1997. 59-70.

8 KIss 1997. 111.

9 KIss 1997. 32.
} 


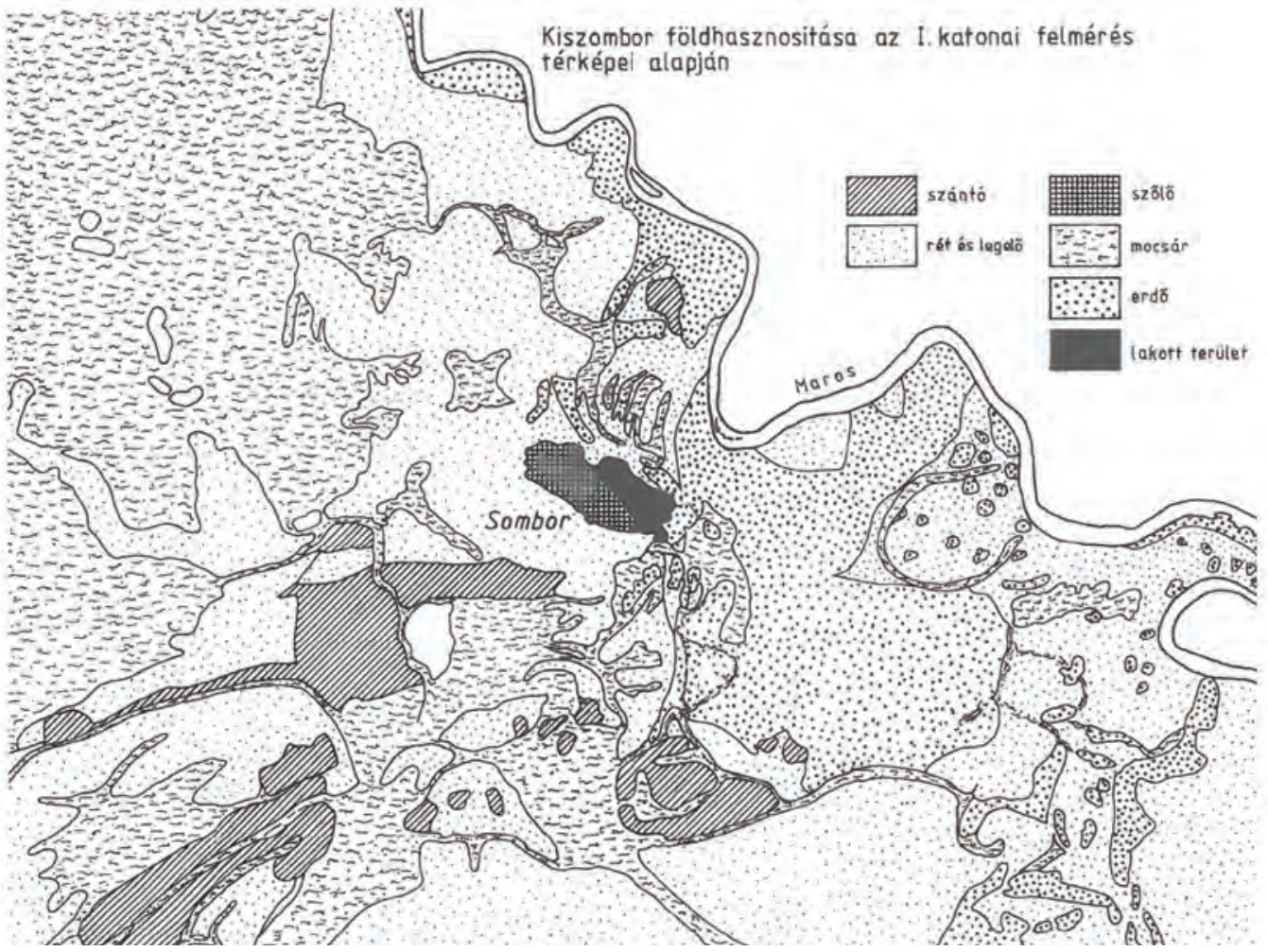

2. ÁBRA Kiszombor földhasznosítása az I. katonai fölmérés térképei alapján (1792-1795) ${ }^{30}$

A település urbáriuma jelentős eltéréseket mutatott a magyarországi átlaghoz képest. Annak érdekében, hogy a török által sújtott területekre munkaerőt csábítsanak, Mária Terézia 1780-ban egy külön urbáriumot adott ki ennek a térségnek, amelyben jelentős kedvezményeket ígért a kormányzat. Az 1782-es telekkimutatás szerint 6 egész, 18 fél, 16 negyed, 77 nyolcad és 15 ház volt telek nélkül. ${ }^{31}$ 3. ÁBRA Zomboraz I. katonai fölmérés idején $(1792-1795)^{32}$

30 KóKAI 2008. 34.

31 Marjanucz 2008. 215.

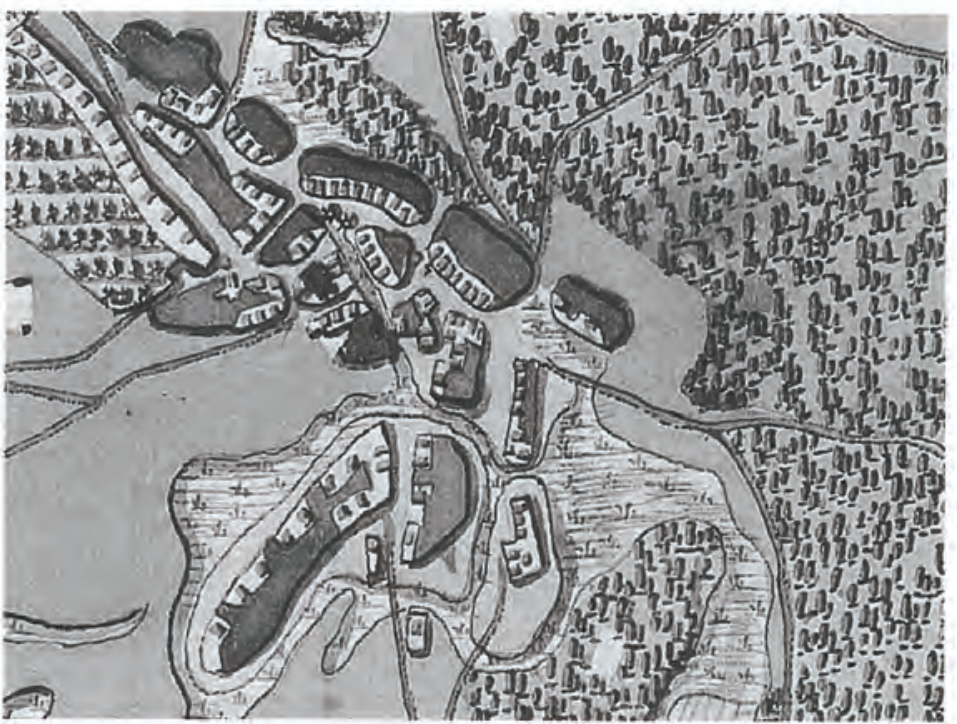

32 Marosvári et al. 2008. 60. 
A társadalmi megoszlásról az 1782-83-84-es robotkönyv ad részletes tájékoztatást. A 149 családból csupán hat volt egésztelkes, akik 24 hold szántóföldet, 6 hold rétet, 3 hold közlegelőt és belsőtelkes járandóságban 1 hold földet, azaz összesen 34 hold földet bírtak. Emellett úrbér fejében fizettek 1 forint kamatpénzt, 33 napi kézirobot megváltását 5 forint 30 krajcárban adtak meg, 29,5 napi kézirobotot természetben fizetett, a kis tizedet pedig 30,5 krajcárért váltottak meg. A féltelkes jobbágyok tizennyolcan voltak, s körülbelül feleannyi földdel rendelkeztek, azaz 12 hold szántóval, 4 hold réttel, 2 hold közlegelővel és 1 hold belsőtelki járandósággal. Kamatpénz fejében 1 forintot, 18 napi kézirobot helyett 3 forintot, a kis tizedért pedig 17 krajcárt fizettek. Ezenkívül még 17 napi kézinapszámot kellett ledolgozniuk. A negyedtelkes jobbágyok kevesen, mindösszesen tizenhatan vannak. Összesen 11 hold földdel rendelkeztek, 2 forint 40 krajcárt fizettek adóban, 11,5 napi robotot természetben. A nyolcadtelkesek 78-an voltak. 7-8 hold földdel rendelkeztek amiért cserébe 1 forint 6 krajcárt fizettek adóban és 13 nap kézirobotot ledolgoztak. Harmincegy zsellér is lakott a faluban, az urasági napszámban vettek részt, földjárandóságuk nem volt, csak házaik. Öket nevezzük a házas zselléreknek. Számuk idővel egyre növekedett, 1805-ben már nyolcvanan vannak. A robotkönyvek alapján lakott a faluban harminckét olyan család, akiknek háza sem volt. ${ }^{33}$ A II. József-féle népszámlálás 1786-ban összeírta a népességi viszonyokat, miszerint 155 házban 176 család élt, ami 975 fö tényleges népességet jelentett. 116 paraszt, 81 zsellér, 6 nemes és 1 pap élt Zomboron. ${ }^{34}$

A birtokvásárláskor az uradalom a következő birtokeloszlást mutatta: 1606 hold erdő, 985 hold erdőtalaj, 725,25 hold erdei kaszáló, 132 hold külön erdő, 5106 hold út, 5083 hold überland. Összesen csak 985 hold volt müvelhető szántóföld, ami viszonylag kevés. Ilyenformán Oexel Mátyás bevétele csupán a fakitermelésből és a jobbágyok által beszolgáltatott terményből tevődött össze. A gazdasági fejlődéshez a birtokosnak több művelhető területre volt szüksége. Az ingoványok lecsapolásához így neki füződött a legnagyobb érdeke. ${ }^{35}$

$\mathrm{Az}$ 1828-as összeírás ugyancsak gazdag forrása a település társadalomtörténetének. Az összeírás tanúsága szerint 138 jobbágy lakta a települést, akik nem mondhatóak jómódúnak, hiszen a legtöbb család (78) nyolcadtelkes. A jobbágyok átlagosan 11,2 hold földdel rendelkeztek. 229-re nőtt a házas zsellérek száma, akik fóképp állattenyésztésből és fuvarozásból éltek meg. Továbbá 26 házatlan zsellért számoltak össze. ${ }^{36}$ A kimutatás nem csak a társadalmi viszonyokat taglalja, hanem a gazdasági helyzetet is. Az állattenyésztés jelentős volt a faluban: 134 ökör, 257 szarvasmarha, 67 borjú, 422 ló, 763 juh és 103 sertés tartozott a 393 úrbéres házhoz. Ez a mezőgazdasági ágazat a földdel nem rendelkező embereket is bevételhez juttatta, ugyanis az állatokat a közlegelőn tarthatták, továbbá a szekerezésnél is segítségükre voltak a marhák és a lovak. ${ }^{37}$

1831. július 30-tól őszig kolera söpört végig a településen, amely a temetési anyakönyvi adatokban is megmutatkozik. A falu lakosságának a 3\%-a elhunyt a járvány első nyolc napjában. A kolerajárvány 1836-ban megismétlődött, de az már nem járt ilyen mértékű pusztítással. 1844ben a falu templomát felújították, majd egy év múlva iskolát is építettek. A felvirágzás azonban nem tartott sokáig. A régiót is érintő hadműveletek következtében 1848 telén a Maroson túlra menekülnek a Szegedtől délre lévő falvakból, azonban Zomborról nincs adatunk erre vonatkozóan. 1849 februárjában rácok törtek be a faluba, felforgatták és kifosztották azt, a lakosság

33 KISs 1997. 32-33.

34 Marjanucz 2008. 218.

35 KIss 1997. 37-38.

36 Marjanucz 2008. 241-242.

37 Marjanucz 2008. 241-242. 
pedig Makóra menekül elölük. A kolera és a harcok következtében csökkent a falu népességszáma. 1851-ben 2586 lelket számoltak a településen, amelyből 2500 katolikus, 20 református és 66 pedig óhitü volt. ${ }^{38}$

\section{Az egyházközség története}

A helytörténeti kutatás feltételezi, hogy Szent István kora óta volt plébánia a településen. Az első okleveles említés ugyanakkor csak 1334-ből származik. A helyi plébánia szervezetileg a csanádi főesperesség alá tartozott. A középkorból szinte semmilyen információval nem rendelkezünk, azonban a gyaníthatjuk, hogy kiemelkedő hely lehetett a csanádi régióban, hiszen több kanonok került ki ebből a faluból (Zombori László 1357-ben csanádi, egy másik Zombori László 1449-ben, Zombori Illés 1454-ben, majd Zombori Márton 1467-70 között aradi kanonok). A török idők alatt római katolikusok éltek a faluban, de plébániával nem rendelkeztek, a szegedi ferences közösség látta el a lelkipásztori teendőket. 1722-ben megkísérelték újraszervezni a plébániát, azonban a kamara úgy döntött, hogy a település nem rendelkezik elég hívővel egy plébánia kialakításához, ezért csak filiális lett. 1753-ra azonban a történeti források tanúsága szerint létrejött a plébánia, minden valószínűség szerint Ladány, Dédényszeg, Porgány, Klárafalva és Ferencszállás filiákkal kiegészülve. Az első plébános Szauer Ádám Ignác volt 1764-1765 között. Helyettese, Unterberger Jakab követte a tisztségben 1769-1771 között. Két év múlva elhelyezi a püspök. 1771-1774 között Gerencsér János a plébános, majd Paraisz Pál adminisztrátor követi 1774-1787 között. Paraisz Pál az első egyházi ember, aki a plébánia újraalapítása óta hosszabb időt tölt el Zomboron. A 13 év alatt restauráltatja a templomot, illetve hajót építtet hozzá, továbbá kéri a hatóságoktól, hogy a papnak szolgáltassanak kocsit a temetéshez. Utóda Kovetsits István 1789-ben Makón elhalálozott. Koltz Bálint piarista pap követte 1789-1797 között, halála után Soók József a plébános, de még az év decemberében elhalálozott. Meszesi Pál minorita atya 1797-1814 között volt plébános a településen. Hosszú müködése után Battonyára diszponálták. Dombó Antal 1814-1818-ig szolgálta Istent Zomboron. Ö áldotta meg 1815. május 16-án a Nepomuki Szent János szobrát. 1818-ban vette át a helyét Horváth Mihály, aki az egyik legkiemelkedőbb plébános volt a 18-19. században. Legfontosabb kezdeményezése a plébánia Historia Domusának vezetése volt. Nem csak a szolgálata alatt történt eseményeket örökítette meg, hanem visszamenőlegesen, a plébánia újraalapításáig igyekezett ismertetni a jelentős eseményeket, részben hallomás, részben a fennmaradt írások alapján. ${ }^{39}$ „Érdeme a szorgalmas és alapos munka, de méginkább, hogy egyáltalán tollat fogott: a kezdés." ${ }^{\text {"40 }}$ Ezután ugyanis mindegyik plébános több-kevesebb szorgalommal papírra vetette a plébánia és a falu élettörténetét, amely nagy segítségére válik az utókornak. Horváth Mihályt 1838-ban Apátfalvára helyezték át, utóda, Drahoss Gergely 16 évet volt a falu lelkipásztora. Sajnálatos módon azonban nem volt olyan szorgalmas, mint elöde, pedig egy nagyon izgalmas korszakon ment keresztül Zombor a szolgálata alatt. 1852-ben a szőregi plébániát vette át, így zombori munkáját be kellett fejeznie. ${ }^{41}$

A plébánia müködéséhez minden korban szükség volt egy templomra. Az Árpád-korban, a 13. században épült a körtemplom (rotunda), amely valószínűleg keresztelő kápolnaként szolgált,

\footnotetext{
38 KIss 1997. 70-71.

39 KIss 1997. 75-79.

40 KIss 1997. 78.

41 KIss 1997. 75-79.
} 
esetleg a Csanád nemzetség magánkápolnája volt. Mindenesetre kiemelkedő fontosságú, hiszen az Alföldön a török hódoltság idején is épségben maradt, ráadásul ilyen alaprajzú kápolnából csak kettő maradt fenn az egész országban. A zombori körtemplom a román és a gót stílus közötti átmenet jegyeit viseli. A benne található 673 éves freskó a 14. század elejéről származik, valószínűleg a falu akkori tulajdonosa, a Csanád nemzetségbeli Tamás festettette. A török korban a templomot nem pusztították el a törökök, mivel formájának köszönhetően mecsetként is jó szolgálatot tett. 1744-ben fatornyos templommá építették át, majd 1776-ban ezt lebontották, és egy barokk stílusú templomot építettek a helyére, amelynek szentélye a körtemplom lett. 1797ben kriptát ástak alá, 1844-ben pedig felújították és kibővítették a templomot, ami változatlan maradt a 19. században. A templomi berendezésekből kitűnik, hogy a kegyúr, 1780 után a mindenkori Oexel családfö, nagy becsben tartotta, és bőkezűen áldozott a templom felszerelésére. ${ }^{42}$

\section{A kiszombori anyakönyvek feldolgozása}

Kutatásaim középpontjában a kiszombori plébánián található anyakönyvek történeti demográfiai szempontú feldolgozása állt. ${ }^{43}$ Az 1830-1839 közötti időszak anyakönyveinek keresztelési, esketési és temetési bejegyzéseit táblázatkezelő program segítségével kivonatoltam, törekedve arra, hogy minden hasznosítható kvantitatív és kvalitatív információt önállóan is elemezhetővé tegyek. A tárgyalt időszakban kétféle anyakönyvvel találkoztam. Az 1830-1835 közötti időszakban teljesen latin nyelven történt a lejegyzés, amely kevéssé volt részletgazdag. 1836-tól egy évig még szintén latin nyelven folyt a lejegyzés, ezt követően azonban magyarul vezette a plébános az anyakönyveket, az információk mennyisége erőteljesen növekedett. Az anyakönyvek bejegyzései a gondos tárolásnak köszönhetően jól olvashatóak voltak.

\section{Keresztelések Kiszomboron 1830 és 1839 között}

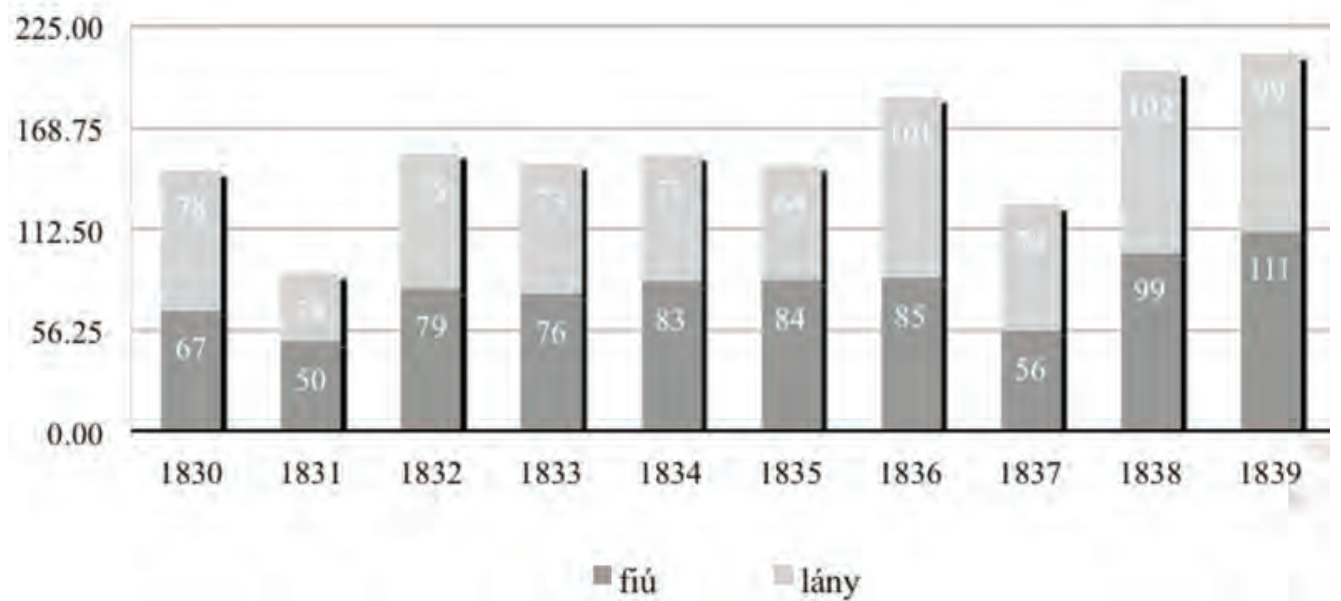

4. ÁBRA * Kereszteltek száma évente Kiszomboron, 1830-1839 (szerk.: Körös Á. 2013)

42 KIss 1997. 80-89.

43 A források elérhetővé és kutathatóvá tételéért köszönetemet fejezem ki - ily módon is - Dr. Kiss-Rigó László megyéspüspök úrnak, valamint Varga Attila esperes és plébános úrnak. 
1831-ben a falu lakossága 2888 lelket számlált. ${ }^{44}$ Amennyiben hat fös családokkal számolunk, akkor ez körülbelül 480-500 családot jelent. Erre a népességre évente átlagosan 155 keresztelés esett, a megkereszteltekből 79 fiú, 77 pedig lány volt (4. ÁBRA).

Az 4. ábrán jól látszik, hogy a keresztelések száma a vizsgált évtizedben növekvő tendenciát mutat. Két nagyobb visszaesést mutathatunk ki: 1831-ben és 1837-ben. Érdekes módon mindkét időszak közel van a kolera járványhoz, amely 1831-ben illetve 1836-ban pusztított Kiszomboron. A keresztelésének nemek közötti megoszlása 50-50\% körül alakult. Négy évben tapasztalhatunk jelentősebb eltérést: 1831-ben a kereszteltek 56,82\%-a fiú, majd 1835-ben szintén a fiúk oldalára billen a mérleg 57,53\%-kal. A következő évben 55,19\%-kal a lányok vannak többen és 1837-ben is hasonló az arány: 55,56\%. Ezeknél az egyensúlyi ingadozásoknál nagyobb eltéréseket nem találtunk.

A keresztelések évszakonkénti eloszlását illetően, viszonylag homogén eredményre jutottam: $21 \%$ és $28 \%$ közötti ingadozás figyelhető meg. Tavasszal és ősszel egy kicsit több gyermeket kereszteltek meg. Ugyanakkor azonban a keresztelési anyakönyvben nincs adat a megkeresztelt személy életkorára vonatkozóan, így nem tudjuk meg, hogy volt-e kivétel a gyermekkeresztség általános gyakorlata alól. Ha a katolikus hagyományokból indulunk ki, miszerint születés után keresztelik meg a gyermeket, következtethetünk arra, hogy ugyanannyi ember született, mint amennyi keresztelt bejegyzés van. A keresztelési anyakönyv tanúsága szerint tavasszal és ősszel többen születtek, mint nyáron és télen. Átlagosan háromhavonta 39,33 keresztséget szolgáltatott ki az egyház.

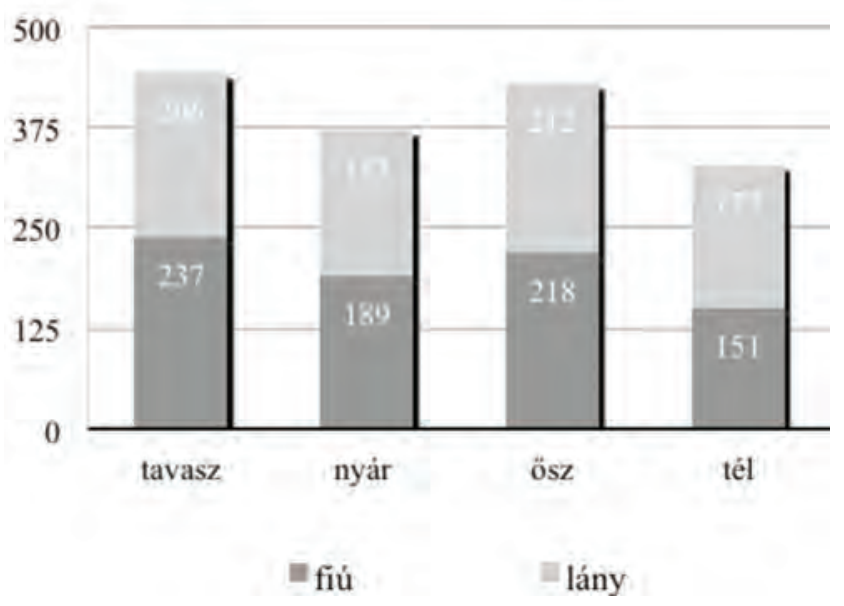

5. ÁBRA Kereszteltek száma évszakonként Kiszomboron, 1830-1839 (szerk.: Körös Á. 2013)

Érdekes mintázatot mutat megkereszteltek nemi arányának változása az évszakok szerint (5. ÁBRA). Tavasszal a fiúk vannak túlsúlyban 53,5\%-kal, majd nyáron és ősszel kiegyenlítődnek a nemi arányok, télre azonban a lányok kerülnek többségbe, 53,96\%-kal. A havi megoszlás már sokkal összetettebb. Havonta átlagban tizenhárom keresztelés volt. A január-február-március, illetve az augusztus az őszi hónapokkal emelkedik ki a többi közül. Ebben a két időszakban összesen tíz év alatt átlagosan 143 embert kereszteltek meg, míg az év többi hónapjában ez az átlag csak 113 ember.

A tíz év alatt összesen 77 név fordul elö a kereszteltek között. Ebből a tíz leggyakrabban előforduló (zárójelben az előfordulások számával): János (127), István (104), Erzsébet (86), András (84), Rozália (84), Katalin (81), Mihály (81), Anna (80), József (80) és Pál (79). A tízes listában hat fiú- és négy lánynév található, ráadásul az első helyeken jobbára fiú nevek vannak, amiből arra következtethetünk, hogy hasonló névadási gyakorlat működött, mint napjainkban: a fiú névadásban a szülők konzervatívabbak, míg a lányok esetében több szerepet kapott az idő tájt

44 KIss 1997. 70. 
is a divat. A konzervatív névválasztás egyik indikátora, hogy a megkereszteltek hány százaléka kapja valamelyik szülője a nevét. Azt feltételeztem, hogy 40-50\% körüli arányt kapok, azonban az egész időszak alatt ez a jelenség csupán 13\%-ban érvényesült.

1836 és 1839 között a keresztelési anyakönyvekben feljegyezték a szülők lakhelyét, foglalkozását és vallását is. Ezek szerint a szülők 82,67\%-a zombori, s minden egyéb település 10\% alatt marad: Klárafalva 6,39\%, Ferencszállás 4,55\%, Nagyporgány 3,27\%, Kisporgány 1,56\%, egyéb 1,56\%. A szülők 93,137\%-uk földművelő, egyetlen más foglalkozási csoport sem éri el az $1 \%$-ot. Vallásukat tekintve két görög katolikussal, egy reformátussal és 1422 római katolikussal találkoztam. Egyetlen olyan család volt, amelyben az apa és az anya vallása nem volt azonos és hat olyan családdal, ahol valamelyik szülő nem lett bevezetve az anyakönyvbe.

\section{Esketések Kiszomboron 1830 és 1839 között}

1830-ban tizennégy esketés volt, ami a legalacsonyabb érték a vizsgált tíz év alatt. ${ }^{45}$ Átlagosan évente 35 esketés történt, a legtöbb, 48 1831-ben. Ahogy a 6. ábra mutatja az esketések számát tekintve 1831-től csökkenő trend mutatkozott egészen 1837-ig, ami csak 1836-ban torpant meg csekély mértékben. 1838-ban azonban az idősor második legnagyobb értékét regisztráltuk, s a házasságkötések száma 1839-ben is magas maradt. ${ }^{46}$

6. ÁBRA Esketettek
száma évente Kiszomboron,
1830-1839 (Szerk.: Körös
A. 2013)
A házasságköté-
sek havi és évszakos
eloszlása pontosan
illeszkedik a tradicio-
nális agrártársadalom

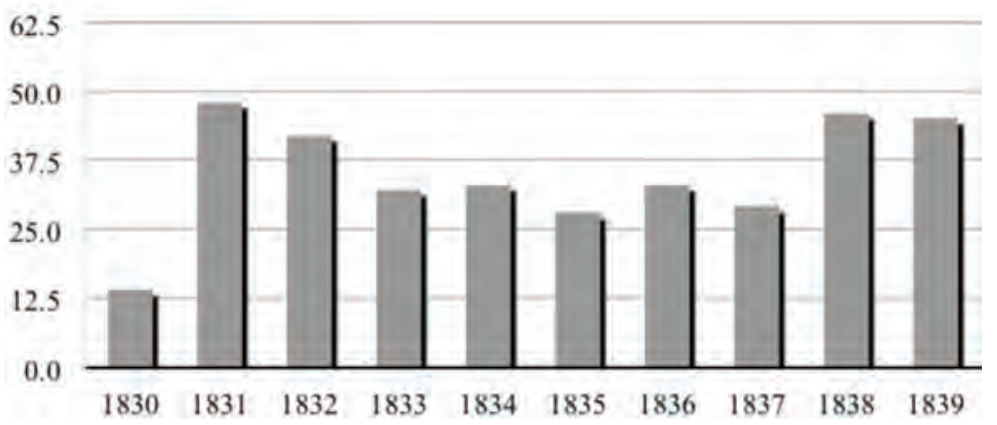
életritmusához. Az esküvői szezon az éves mezőgazdasági munkálatok befejezése után kezdődött. Nyáron nagyon kevés házasságot kötöttek, mindösszesen 26-ot, ami az esküvők csupán a 7\%-a, de a tavaszi érték még ennél is kevesebb, mindössze $6 \%$ volt. A tenyészidőszakban a mezőgazdasági munkák anynyira lefoglalták az embereket, hogy sem idő, sem energia nem maradt a nagyobb rendezvények szervezésére, az ünneplésre. Akik mégis ekkor esküdtek, azok esetében feltételezhetjük, hogy a leendő feleség már áldott állapotban volt, s a házasság megkötése nélkül a gyerek törvényessége került volna veszélybe. Az esküvői szezon az ősz derekén kezdődött el. A vizsgált évtizedben szeptemberben átlagban négy friggyel számolhatunk (a havi átlag 29,25). Októberben már 25 házasság köttetett, novemberben köttetett azonban a házasságok 49,57\%-a. Az esküvők szervezői ugyancsak favorizálták a januárt (17,38\%) és a februárt (11,40\%) is. Figyelemreméltó azonban, hogy a két csúcsidőszak között decemberben a tíz év alatt csak egyetlen házasság köttetett. Ennek minden valószínűség szerint az adventi ünnepkör és a karácsonyi ünnepek „konkurenciája” lehetett az oka.

${ }^{45}$ Itt érdemes lenne az előző öt-tíz évet megnézni, hogy vajon ez az érték egy csökkenési folyamatnak a része, vagy egyszeri eset?

${ }^{46}$ Itt szintén érdemes lenne megnézni a következö öt-tíz évet, hogy vajon újra egy csökkenési tendencia megy-e végbe? 
7. ÁBRA Az esketettek megoszlása évszakonként Kiszomboron, 1830-1839

(Szerk.: Körös Á. 2013)

Az átlag házasodási kor ebben az időszakban férfiak esetében 25,725 év, míg a nőknél 21,700 év. Ez összevetve 23,713 év, ami az adott tradicionális világ normáinak megfelel. ${ }^{47}$ Szerencsére az anyakönyv tartalmaz információt arra vonatkozóan, hogy a házasulandó feleknek mi volt a családi állapota, így megkülönböztethetjük az első házasságokat a többedik házasságoktól. A 8. ábra mutatja, hogy az első házasság esetében a férfiak átlagéletkora 21,48 év, míg a nőké 18,69 év volt, ami 2,79 év különbséget jelent. Általános tendencia, hogy a házasulandó felek közül a férfiak az idősebbek, így van ez a többedik házasság esetén is: a férfiak átlag életkora 38,54 év, míg a nőké 35,445 év, ami már 3,095 év különbséget jelent. A 700 házasságból 150 (21\%) volt többedik házasság. A vizsgált adatok alapján a házasságok $9 \%$ ában fordul elö, hogy a férj már a második házasságát köti, míg a feleség csak az elsőt, továbbá a házasságkötések 3\%-ában ez fordítva történt. Az összes többi (88\%) esetén mindketten első vagy többedik házasságukat kötötték.

8. ÁBRA Azátlag házasodási kor Kiszomboron, 1830-1839. (szerk.: Körös Á. 2013.)

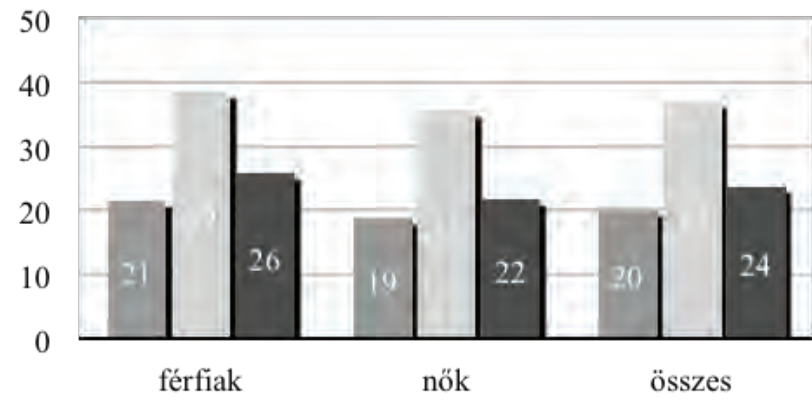

A házasodási életkor esetében nem csak az átlagértékek érdeke-

\section{Első házasság 嘼 többedik házasság}

" összes sek, legalább olyan fontos demográfiai mutatót jelentenek a házasodási életkor szélső értékei is. Külön csoportosítottam a nőket és a férfiakat, illetve az első házasságkötés és a többedik házasságkötés alkalmait. Az 1. táblázatban szereplő adatokat kaptam eredményül.

\begin{tabular}{c|c|c|c|c}
\multirow{2}{*}{} & \multicolumn{2}{|c|}{ Férfi } & \multicolumn{2}{c}{ Nö } \\
\cline { 2 - 5 } & Minimum (év) & Maximum (év) & Minimum (év) & Maximum (év) \\
\hline Házasulatlan & 17 & 50 & 15 & 41 \\
\hline Özvegy & 19 & 70 & 18 & 60
\end{tabular}

1. TÁblázat Házasodási szélsőértékek Kiszomboron, 1830-1839 (Szerk.: Körös Á. 2013)

$\mathrm{Az}$ átlag kor mellett a korkülönbségek is érdekesek, főként abban a kontextusban, mely szerint megállapítható, hogy a férfiak általában idősebbek a nőknél a frigy megkötésekor. Az átlagként kapott koroknál a már felállított csoportokat hoztam létre, és ezek alapján számoltam ki az eredményeket. Az esetek 88\%-ában a férfiak idősebbek, 7\%-ban egyenlő korúak és csupán 5\%-

\footnotetext{
47 A későbbiekben kitérek még az átlag életkorra, de az összehasonlítás végett itt is megjegyezném, hogy az átlag életkor a csecsemőhalandósággal együtt 18,811 év volt. Tehát a házasodási átlag életkor magasabb, mint a születéskor várható átlag élettartam.
} 
ban a nők idősebbek a házassági kapcsolatokban. Az átlag korkülönbség férfiak első házasságában 3,25 év, majd a többedik házasságban ez a szám 9,10-re emelkedik. A nők első házasságában 4,00 év az átlagos korkülönbség. A többedik házasság korkülönbsége a nők esetében kevesebb, mint a férfiaknál, csak 8,14 év. Tehát elmondható, hogy az első házasságban az átlagos korkülönbség 3,62 év, a többedik házasságban 8,62 év, az összes házasságban pedig 6,12 év.

9. ÁBRA Átlagos házasodási korkülönbség Kiszomboron, 1830-1839 (Szerk.: Körös Á. 2013)

A korkülönbség eloszlása esetszámban sem egyenletesen alakul, ahogyan az a 10. ábrán látható. Nyilvánvalóan az

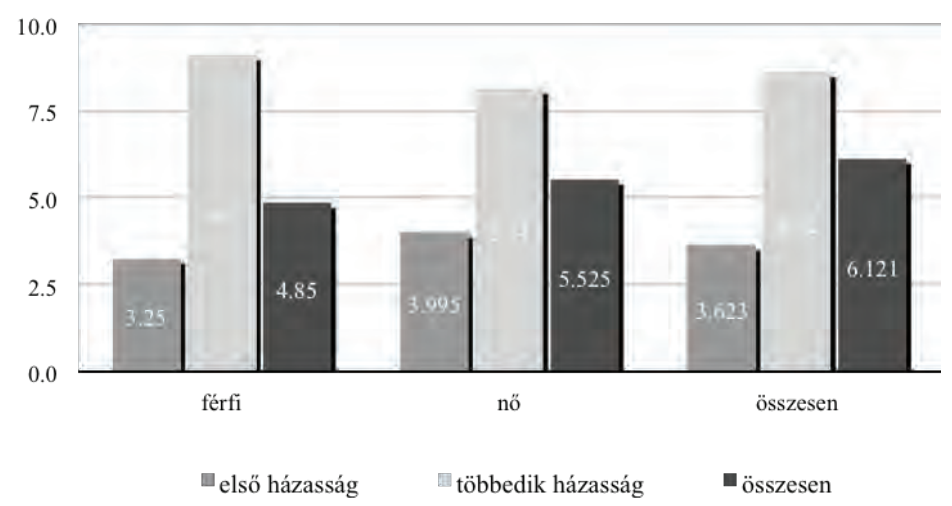
egyre nagyobb különbség egyre kisebb gyakorisággal fordul elő. Mint már említettem az esetek 7\%-ában azonos korúakról beszélhetünk. Az 1-5 év közötti korkülönbség a férfiak javára 217 alkalommal figyelhetö meg (azon házasságoknak, melyben a férfiak idősebbek, 72\%-a, az összes házasság 62\%-a), ez több, mint a házasságok fele. A nőknél ez a korkülönbségcsoport kilenc esetben valósult meg, ami a női kortöbblettel rendelkező házasságoknak a 53\%-a, azonban az összes házasságnak csak 3\%-a. A 6-10 év különbség a férfiaknál 58 alkalommal fordult elő (19\%, illetve 17\%), ezzel kapcsolatban ismét elmondható, hogy bár nem átlagos, de nem tekinthette a kor embere furcsa jelenségnek. A nők esetében a vizsgált időszakon belül hétszer fordult elő ilyen eset (41\%, illetve 2\%). 11-15 év közötti korkülönbséggel rendelkező házasságkötések a férfiak javára 23 alkalommal történtek (7,59\%, illetve 6,57\%). A nők esetében egyetlen alkalomról számolhatunk be (5,88\%, illetve 0,29\%), ami azt jelenti, hogy már a férfiak esetében is ritka volt ekkora korkülönbséggel házasodni, a nők esetében pedig még inkább. További két kategória maradt: 16-20 év közötti korkülönbség, ahol a férfiak három esetben képviseltetik magukat (0,99\%, illetve 0,86\%) és a huszonegynél több év, ahol szintén a férfiak felé billent a mérleg nyelve két alkalommal (0,66\%, illetve $0,57 \%)$. A nők javára nem volt ekkora korkülönbség. Összességében elmondható, hogy nagyon ritkán ugyan, de akár egy évtized is lehet a különbség a két házasulandó életkora között, de a legtöbb esetben 2-4 évvel a férj volt az idősebb.

10. ÁBRA * A házasodási korkülönbségek megoszlása korcsoportonként Kiszomboron, 1830-1839 (Szerk.: Körös

Á. 2013)

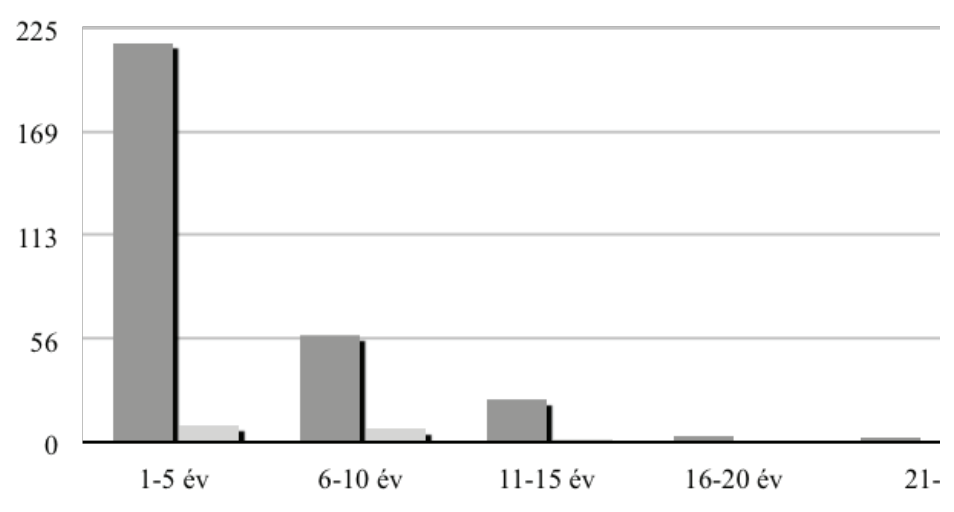


Az anyakönyvi adatokban lejegyezték, hogy a házasulandó felek hol laknak. Sajnos arra nincs adatunk, hogy ez akkoriban pontosan mit jelent (lakhely vagy származási hely), ugyanakkor mivel 1836-1839 közötti bejegyzésekben már külön írták - utóbbiról úgy vélem, hogy a születési helyet jelentette, illetve a házasságkötést megelőző lakhelyet jelöli, nem pedig azt a helyet, ahol később családként le fognak telepedni. ${ }^{48}$ Megvizsgáltam, hogy hol lakik a másik házastárs, amennyiben a férj zombori, illetve amennyiben a feleség zombori. Ha a férj zombori származású, akkor az esetek 89,8\%-ában a feleség is zombori, 4,7\%-ban klárafalvi, 1,6\%-ban porgányi, 1,2\%-ban nagyporgányi. Kisporgány, Ferencszállás és Deszk nem érte el az 1\%-ot sem, továbbá két esetben fordult elő, hogy nem jelölték meg a feleség lakhelyét. Amennyiben a feleség volt zombori, abban az esetben, az adatok szerint a férj sokkal több helyröl érkezhetett: $81,9 \%$-uk Zomborról, 3,9\%-uk Makóról, 1,4\%-ot képviselt külön-külön Klárafalva és Nagyporgány, 1,1\%ot külön-külön Óbessenyő, Verbitza és Ferencszállás. Az 1\%-ot nem érte el Apátfalva, Battonya, Beba, Czerna Bara, Halas, Kikinda, Kisoroszi, Kotsorház, Majdány, Monostor, Oroszlányos, Palota, Porgány, Rábé, Ráckeresztúr, Szeged, Szőreg, illetve Térvár. Ezen kívül itt is szólhatunk egy olyan esetről, amikor nincsen bejegyezve a férj lakhelye. Tehát összességében elmondható, hogy a zombori férfiak 10\%-a választott feleséget magának a falun kívülröl. Ezek pedig csakis olyan helyek voltak, amelyek alapvetően 10 kilométeren belül helyezkednek el. Ezzel szemben zombori leányok 18\%-a választott párt magának másik településről. Ezeknek a településeknek a 23,5\%-a 25 kilométeren kívül esett.

\section{Halálozások Kiszomboron 1830 és 1839 között}

A vizsgált tíz évben az anyakönyvben összesen 1195 temetési bejegyzést találtam. Pontosan eggyel több férfi halt meg, mint nő. Havonta átlagosan 120 temetés volt a faluban, a férfi-nő arány teljesen kiegyensúlyozott: 59,8 férfit és 59,7 nőt temettek el átlagosan havonta. Ettől az aránytól jelentős eltérés amikor bármelyik fél 55\%-nál többet képviselt - csak négy alkalommal mutatkozott meg. 1832-1834 között a férfiak $56 \%$, $57,35 \%$ és $55,71 \%$-ot képviseltek, majd a következó évben ez visszaesett $49,59 \%$ ra. A negyedik alkalommal, 1838-ban a nők számaránya kiugró a halálozások

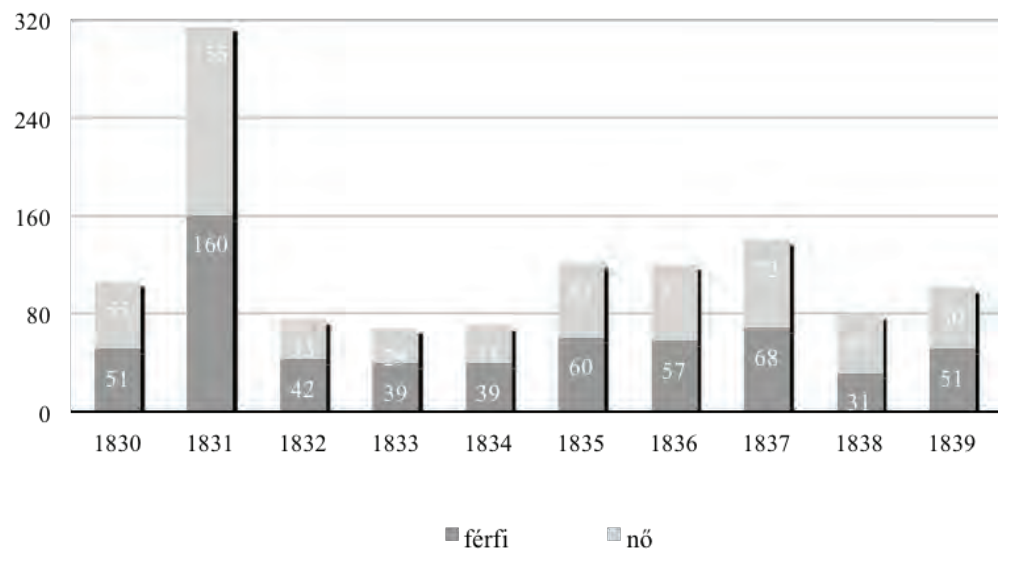
tekintetében: $60,76 \%$.

11. ÁBRA * Temetettek száma évente Kiszomboron, 1830-1839. (szerk.: Körös Á. 2013.)

${ }^{48}$ Valószínűsíthető, hogy ez az egyikük lakhelye lesz, azonban erre nincsen adatunk. 
A vizsgált időszakban kétszer volt kolerajárvány a faluban. 1831-es bejegyzésekből kiderül, hogy a kolera hatalmas pusztítást okozott. Kiss Mária Hortensia szerint 1831. július 30-án kezdődött a pusztulás, és az első nyolc nap alatt 94 ember vesztette életét. ${ }^{49} \mathrm{~A}$ temetési anyakönyvi bejegyzésekből az is kiderül, hogy ez év alatt, október 6-ig 148 ember vesztette életét a kolera miatt. Ebből 80 férfi és 68 nő. A halottak átlagéletkora 30,02 év volt. A halottak 37\%-a tíz évnél fiatalabb volt, és majdnem ugyanennyi, 38\% a 41 évnél idősebbek aránya is, ahogy azt a 12. ábra jól érzékelteti. Szembetűnő, hogy a betegség főleg az egészségügyileg kiszolgáltatottabb körülmények közt élőket, a gyermekeket és az időseket sújtotta. Az 1836-os kolerajárvány a temetési anyakönyvekben nem jelenik meg. Egyrészt a megjegyzésekben csupán a szentségek felvételét, vagy annak elmaradását, illetve ez utóbbi esetében annak okát tüntették fel, másrészt az elhalálozottak száma sem kiugró annyira, hogy felfedezhető legyen

a járvány hatása. Kiss Mária Hortensia ugyanakkor azt írja, hogy „a kolerajárvány 1836-ban megismétlődött, de erről nincs bejegyzés [a Historia Domusban, a szerző], mert a falu buzgó krónikás papját éppen ez évben disponálták Apátfalvára". ${ }^{50}$ Ezen két adatból arra következtethetünk, hogy a járványnak második hulláma már nem okozott olyan mértékű pusztítást, mint a korábbi.

Átlagosan a legtöbb elhalálozás nyáron történt, 35,3 fö; a legkevesebb pedig télen, 24,3 fö. A nemek aránya folyamatosan kiegyensúlyozott, az 50-50\%-tól soha nem tért el jelentős mértékben. A havi eloszláson is látszik az 1831-es kolera pusztításának hatása. Augusztusban volt a legsúlyosabb a helyzet, amikor összesen 183 haláleset történt, ezt április követte 116 elhunyttal. A havi

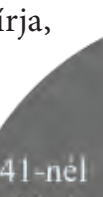
41-nél több év $38 \%$

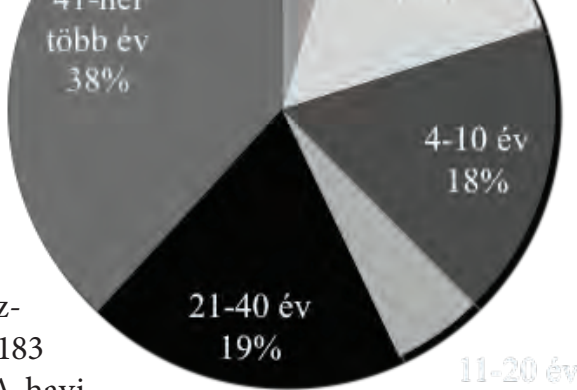
átlag 9,9 elhalálozás az egész évben.

12. ÁBRA * Kolerában elhalálozottak aránya az 1831-es kolerajárványban életkorcsoportok alapján (Szerk.: Körös Á. 2013)

Az elhalálozottak átlagos életkora 18,96 év volt. Ebbe az átlagértékbe a csecsemőkorban elhunytak is számba vétettek. Különböző korcsoportok létrehozásával igyekeztem megtalálni azokat a határvonalakat, ahol eredményesebb elörelépés van az átlagéletkor növekedésében. Emellett megvizsgáltam egy-egy korcsoporton belül a férfi-nő arányokat is. A teljes adatbázist alapul véve nincs nagy eltérés a két nem között. Azon férfiak, akik már megélték a harmadik életévüket átlagosan 36,30 évesen, míg ugyanezen nők 3,53 évvel korábban, 32,77 évesen hunytak el. Ez a különbség 1,78 évre csökken azok körében, akik már megélték a 14. életévüket: még mindig a férfiak halnak meg később 46,64 évesen, szemben ezzel a nők 44,86 évesen. Azok az emberek, akik megélték a 25. életévüket átlagosan még 26 évet éltek; a férfiak ebben az esetben 53,08 évesen haltak meg, a nők azonban 50,56 évesen, így a különbség újra növekszik.

\begin{tabular}{c|c|c|c|} 
& Férfi & Nő & Összes \\
\hline Összes & 18,78 & 18,75 & 18,81 \\
\hline
\end{tabular}

\footnotetext{
49 KIss 1997. 70.
}

50 KIss 1997. 70. 


\begin{tabular}{|c|c|c|c|} 
& Férfi & Nő & Összes \\
\hline $3+$ & 36,30 & 32,77 & 34,48 \\
\hline $14+$ & 46,64 & 44,86 & 45,72 \\
\hline $25+$ & 53,08 & 50,56 & 51,81 \\
\hline
\end{tabular}

3. TÁBLÁzAt A várható élettartam változatai bizonyos életkorokban Kiszomboron, 1830-1839.

(Szerk. Körös Á. 2013.)

A férfiak 30\%-a halt meg egy éves kora előtt, míg a nőknél ez az arány kisebb, 26\%. A férfiak 49\%-a nem érte meg a 4 éves kort, míg a nők 47\%-a halálozott el ugyanezen kor előtt. Érdekes módon ez a különbség kisimul 24 éves korig, ugyanis ez alatt elhalálozott férfiak és nők aránya egységesen 69\%. Mivel a szülések 14-44 éves kor közé tehetőek, megvizsgáltam, hogy vajon az elhalálozási adatokból következtethetünk-e a magas gyermekágyi halandóságra, azonban úgy vélem, negatív eredmény jött ki. Ebben az összetett korcsoportban a nők 20\%-a halálozott el, a férfiaknál ez az adat viszont 18\%. A két százalékpontos eltérést lehet a szülés miatt bekövetkező elhalálozás számlájára írni, mégsem mondhatjuk azt, hogy jelentős életveszélyt jelentett a szülés az anyára. 45 év felett a férfiak 22\%, a nők 19\%-a halálozott el.

Felállítottam a nemek megkülönböztetése nélküli vizsgálathoz egy másik korcsoportosítást, amely talán jobban reprezentálja az elhalálozásokat (13. ábra). Eszerint a halottak 29\%-a 1 év alatti, 1-6 éves kor között 27\%, 7-14 éves kor között 6\%, 15-22 éves kor között 5\%, 23-40 éves kor között 11\%, majd 41-60 éves kor között 13\% és 61 év felett 9\%. Ebből következtethetö, hogy magas volt a csecsemő- és gyermekhalandóság, összesen több, mint a született gyermekek fele meghalt a hatodik életéve előtt. A serdülő- és a fiatal felnőttkorban az elhalálozások alacsony számban fordultak elö, azonban az érték 23 év felett elkezd növekedni és innentől már akár természetes halállal is haltak meg emberek. Figyelmet érdemel, hogy a természetes öregségben általánosan 41 év felett haltak meg, ugyanis erre van a legtöbb adat, 61 év feletti elhalálozás már negyvennyolccal kevesebb, mint az előző korcsoport értéke.

13. ÁBRA * Azelhalálozások száma korcsoportonként

Kiszomboron, 1830-1839

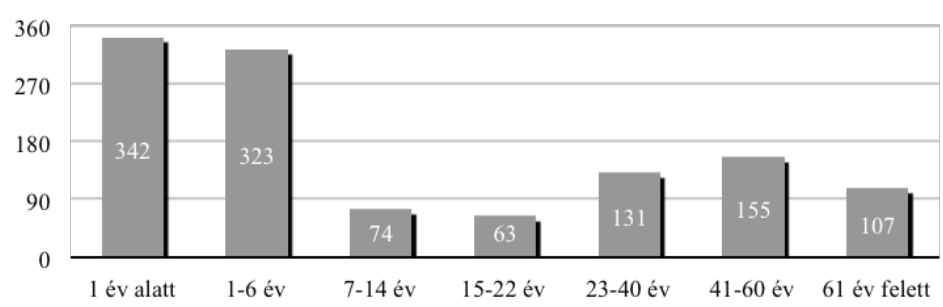

(Szerk.: Körös Á. 2013)

Ugyanebben a felosztásban megvizsgáltam, hogy az egyes korcsoportok átlagéletkorai közötti különbség hogyan változik. Az eredmények a 14. ábrán láthatóak. Aki megélte az első életévét az 7,5 évvel élt átlagosan többet, majd ez tovább növekedett 13,1 évvel, ha a hatodik életévét is betöltötte. Innentől kezdve körülbelül tíz évekkel növekszik az átlagéletkor: huszonkét éves korában az ember már 10,4 évvel többre számíthatott, mint hat éves korában, a negyvenedik születésnapján még 9,4 évet adhatott hozzá a korábbi értékhez, majd ha abban a szerencsés helyzetbe került, hogy megélte a 60. életévét is, akkor még 11,2 évet számolhatott rá átlagosan. Tehát megállapíthatjuk, hogy az egyes korcsoportok átlag elhalálozási életkorai között tíz év különbség van. 


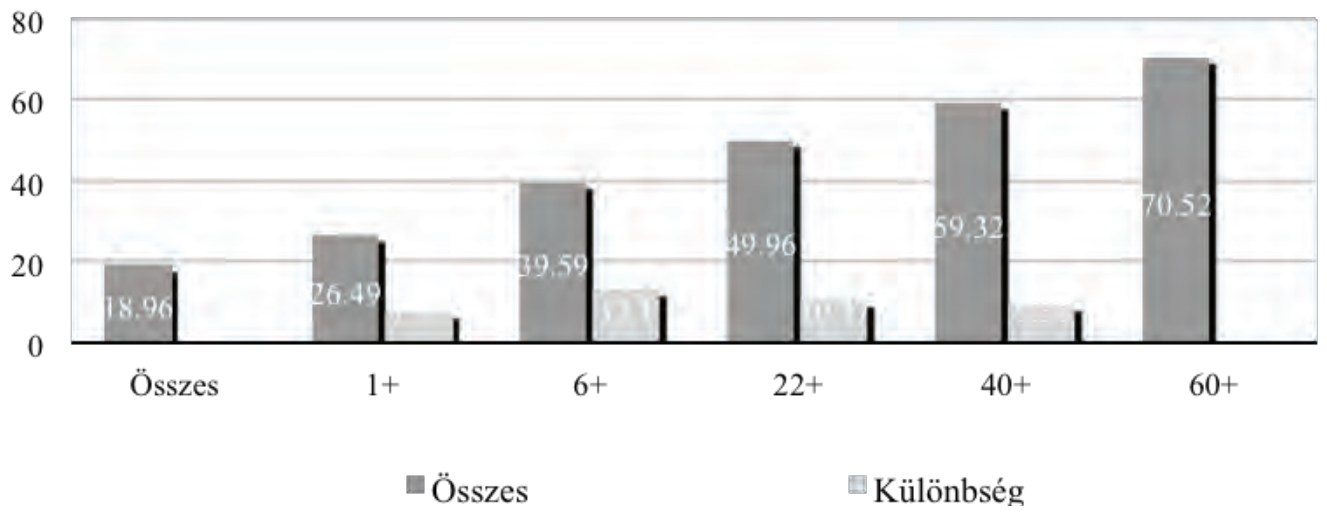

14. ÁBRA :Azátlag elhalálozási életkorok az egyes korcsoportokban és azok különbségei Kiszomboron, 1830-1839 (Szerk.: Körös Á. 2013)

\section{A népesedési folyamatok kölcsönhatásai Kiszomboron}

Úgy vélem nem haszon nélküli megvizsgálni a népesedési folyamatok némely belső öszszefüggését. Elsősorban

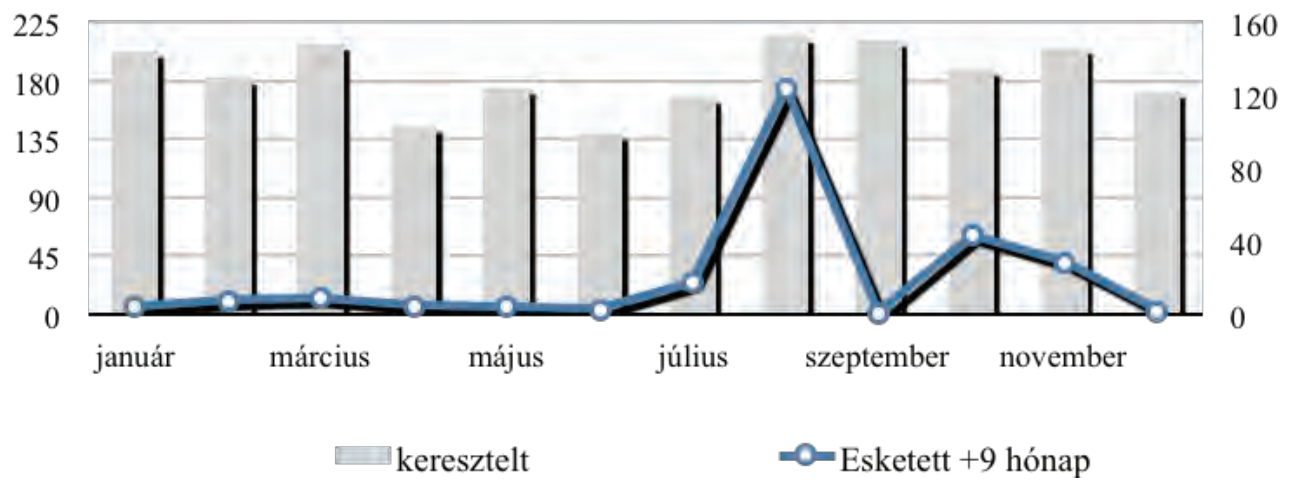

15. ÁBRA A házasságok számának viszonya a keresztelések számához Kiszomboron, 1830-1839 (Szerk.: Körös Á. 2013)

arra voltam kíváncsi, hogy vajon a születések számából lehet-e következtetni a házasodás időpontjára, illetve fordítva. A 15. ábrán az oszlopok a keresztelési bejegyzések számát mutatják, a jobb tengely alapján.

Sajnálatos módon az adatokból nem derül ki, hogy a szülők milyen idősek, így egyáltalán nem lehet következtetni arra, hogy első vagy többedik házasságból származik a gyermek, illetve azt sem lehetett megállapítani, hogy hanyadik gyermekről van szó. ${ }^{51}$ A házasodások havi számát pedig eltoltam kilenc hónappal, így felállítva egy olyan modellt, amelyben a házasságok minden esetben azonnali gyermeknemzést feltételeznek. Ezen értékeket a vonaldiagram mutatja a bal tengely alapján. Arra számítottam, hogy augusztus-szeptember hónapokban, de talán a

${ }^{51}$ Mivel a keresztelt életkora sincsen feltüntetve azt sem tudjuk biztosan, hogy gyermekröl van-e szó. 
koraszületések miatt még júliusban is több keresztelést figyelhetek meg. Ettől eltérő eredmény született. Bár augusztusban volt átlagosan a legtöbb keresztelés, a november, január és március hasonló is értékekkel rendelkezik.

Továbbá arra is kerestem a választ, hogy milyen kapcsolatban állnak a keresztelések - ezzel együtt megbecsülve a születések - a temetésekkel, azaz az elhalálozásokkal? Különös tekintettel az 1831-ben kiemelkedő halálozásokkal, amit a kolerajárvány idézett elö. Azt feltételeztem, hogy ahogyan a háborúk utána a társadalom úgymond újratermeli a férfi populációt, azaz háborúk után sokkal több férfi születik, mint nő, úgy itt is kimutatható lesz, hogy a falu társadalma reagált a pusztításra és egyre több gyermek születik. Ennek adatait a 16. ábra mutatja. Az eredményből arra a következtetésre jutottam, hogy ilyen kis időintervallumot vizsgálva ez nem mutatható ki, mivel 1835-ig inkább csökkenés mutatkozik, majd 1836-ban - a második kolerajárvány idején - jelentős növekedés volt tapasztalható, de 1837-ben már visszatér korábbi csökkenő pályára, és csak a vizsgált kor utolsó két évében emelkedik ki újra a keresztelések száma. Azt is érdemes ugyanakkor megemlíteni, hogy 1837-ben több haláleset volt, mint keresztelés, így az 1838-1839es adatokhoz ez a visszaesés is hozzájárulhatott. A vizsgált évtized népesedési folyamatainak megértéséhez elkerülhetetlen a megelőző és az elkövetkező évtizedek anyakönyvi forrásanyagának feldolgozása.

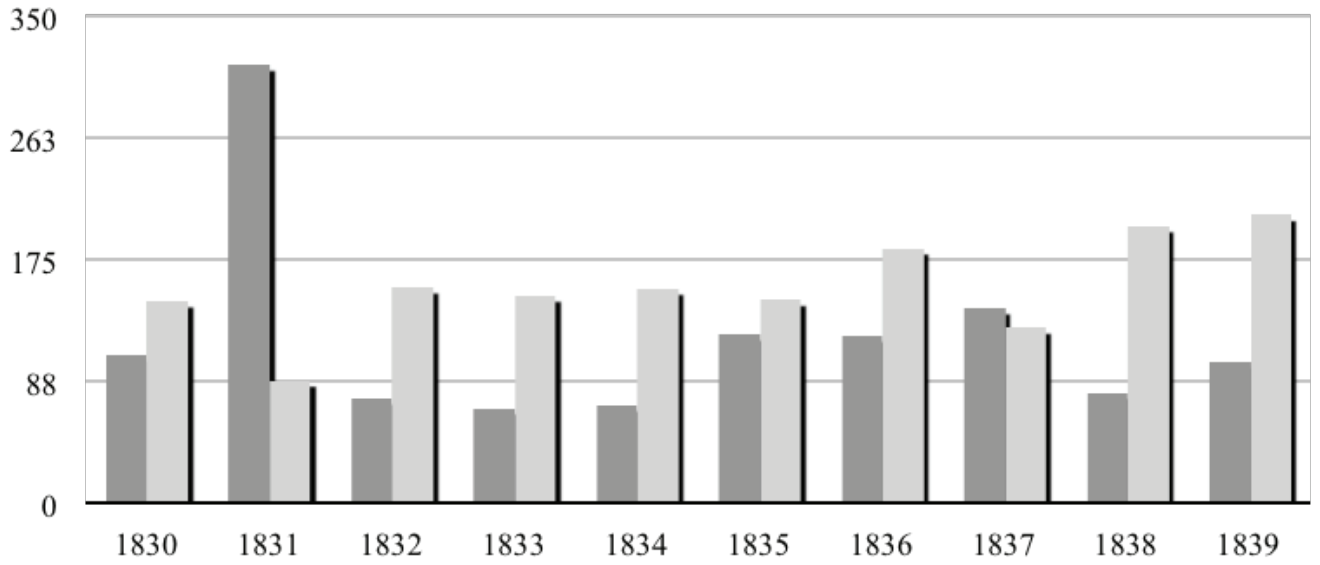

Temetett

Keresztelt

16. ÁBRA A temetések számának és a keresztelések számának viszonya Kiszomboron, 1830-1839 (Szerk.: Körös Á. 2013)

\section{FELHASZNÁLT IRODALOM}

Csorba, L. (2000) A tizenkilencedik század története, Budapest, Pannonica Kiadó.

Faragó, T. (2006) Történeti Demográfia. In Bódy, Z. - Kovács, Ö. J. (Eds.): Bevezetés a társadalomtörténetbe. Budapest, Osiris.

Fleury, M. - Henry, L. (1956): Des registres paroissiaux a l'histoire de la population : manuel de dépouillement et diexploitation de liétat civil ancien, Paris, L'Institut National d'Etudes Demographiques. 
FuInn, M. W. (1981): The European Demographic System, 1500-1820. Baltimore, The Johns Hopkins University Press.

GiLICZE, J. (2008): A zombori Rónay család. In Marosvári, A. (szerk.): Kiszombor története. II. Kiszombor, Kiszombor Község Önkormányzati Képviselö-testülete.

Gutmann, P. M. (1994): Demography. In Stearns, N. P. (Ed.): Encyclopedia of Social History. New York, London, Garland.

KAtus, L. (2010) Magyarország a Habsburg Monarchiában (1711-1918). IN ROMSICS, I. (Ed.) Magyarország története. Budapest, Akadémiai Kiadó.

KIss, M. H. (1997): Kiszombor története, Makó, Kiszombor Község Önkormányzata.

KóKAI, S. (2008): A település földrajzi környezete. In Marosvári, A. (szerk.) Kiszombor története. I. Kiszombor, Kiszombor Község Önkormányzati Képviselö-testülete.

Kovacsics, J. (Ed.) (1963): Magyarország történeti demográfiája, Budapest, Közgazdasági és Jogi Kiadó.

Kovacsics, J. (1988): Tanulmányok a Településdemográfia és a Történeti Demográfia köréböl, Budapest, Tankönyvkiadó.

Kováts, Z. (1983): A debreceni és szegedi népesedéstörténeti kutatások módszertani tapasztalatai. A Juhász Gyula Tanárképző Főiskola tudományos közleményei. Szeged, 1975-1983.

Kováts, Z. - Tóth, P. C. (1962): Csurgói jobbágy-családok demográfiai viszonyai (1720-1950). In EMBER, G. - DÁvid, Z. (szerk.) Történeti Statisztikai Évkönyv 1961-1962. Budapest, Statisztikai Kiadó.

Marjanucz, L. (2008) A török kiüzésétől 1849-ig. In Marosvári, A. (szerk.): Kiszombor története. I. Kiszombor, Kiszombor Község Önkormányzati Képviselö-testülete.

Marosvári, A. - PAP, Á. - Sipos, G. (2008): A falukép. Mủemlékek. In Marosvári, A. (szerk.): Kiszombor története. II. Kiszombor, Kiszombor Község Önkormányzati Képviselö-testülete.

ŐRI, P. (1998.): Paradigmaváltás a francia történeti demográfiában? Demográfia, 41.

PÉczely, G. (1998): Éghajlattan, Budapest, Nemzeti Tankönyvkiadó.

Томка, B. (2009): Európa társadalomtörténete a 20. században, Budapest, Osiris.

Turner, F. J. (1976): The frontier in American historiy, Huntington, N. Y., Robert E. Krieger Publ. 